${ }^{1}$ Graduate Program in Dentistry. Federal University of Pelotas, Pelotas, RS, Brazil

${ }^{2}$ Graduate Program in Dentistry Universidade do Vale do Taquari, Lajeado RS, Brazil.
Corresponding author: Luiz Alexandre Chisini Graduate Program in Dentistry Universidade do Vale do Taquari Adress: 171, Avelino Talini St. Lajeado - RS - Brazil ZIP: $95914-014$ Pelotas, Brazil

Phone/fax: $+555137147000 / 5454$ e-mail: alexandrechisini@gmail.com

Received: November 25, 2018 Accepted: March 30, 2019

\section{Methods and logistics of an oral health cohort of university students from Pelotas, a Brazilian Southern city}

\author{
Luiz Alexandre Chisini ${ }^{12^{2}}$, Mariana Gonzalez Cademartori', \\ Kauê Collares ${ }^{1}$, Sandra Beatriz Chaves Tarquinio', Marília \\ Leão Goettems ${ }^{1}$, Flávio Fernando Demarco ${ }^{1}$, Marcos \\ Britto Corrêa ${ }^{1}$, Marina Souza Azevedo ${ }^{1}$
}

Aim: This paper aimed to describe the methodological aspects in the baseline of university students' cohort in a public university in southern Brazil. Methods: A multidisciplinary study was carried out assessing the psychosocial and oral health conditions of university students at the Federal University of Pelotas (UFPel). All new university students who have entered in in UFPel in the first semester of 2016 year were invited to participate. Two self-administered questionnaires were applied in classrooms. Descriptive analysis was performed using Stata 14.0. Results: A total of 3,237 students were eligible. Of these, $2,089(64.5 \%)$ signed the consent form to participate of the study and answered the general questionnaires, and 2,052 (63.4\%) students answered the confidential questionnaire. Refuses represented only $1.4 \%(n=29)$ of the total sample. Overall, most of the sample was female (52.2\%), with age ranging from 18 to 24 years $(66.1 \%)$, with white skin color $(74.1 \%)$ and with mothers with educational level at university course (32.4\%). A total, $62 \%$ reported a family income between 1001.00 and 5000.00 $\mathrm{BRL}$, while only $16.3 \%$ reported being from low-income family ( $\leq 1000.00 \mathrm{BRL}$ ). The UFPel offers 63 classroom-based courses classified in nine areas of knowledge. The Applied Social Sciences area comprised $19 \%$ of the sample followed by the Linguistics, Letters and Arts (17\%) area and the Health sciences area (13\%). Conclusion: To the knowledge of researchers, this was the first cohort study of university students in the South of Brazil including more than two thousand participants. This paper described strategies adopted to optimize and to allow data collection in the baseline and in the next follow-ups.

Keywords: Epidemiology. Surveys and questionnaires. Oral health. Methods. 


\section{Introduction}

In the last decades, there was a significant increase in number of individuals attending to the Universities in Brazil, reaching around 8 million in 2015 (3.9\% of the Brazilian population $)^{1,2}$. Most of students who have entered in the university are yet youngers, considered as young adults. This phase of life is known as the period where individuals are building up their personalities and, in many cases, coincides with a change of city and with the departure of the parents' house $e^{3,4}$. It is important to point out that some of the habits developed during this period of life can be into adulthood ${ }^{5}$ and, thus, the health of the population of university students should be among the priorities of higher education institutions ${ }^{6}$.

In this same line, oral diseases have an important psychosocial component that may be influenced by deep and abrupt changes in the individual's life. Untreated dental caries, periodontal disease and severe tooth loss affect $36 \%, 11 \%$ and $2 \%$ of the global population, respectively ${ }^{7}$, being considered a public health problem, in which the main preventives and interventional approaches must be directed both to individual as to population level $\left.\right|^{8,9}$. The National Oral Health Survey performed in 2010 (SB-2010) observed that adolescents (15 to 19 years old) presented a mean of 4.25 teeth decayed, missing or filled as well as $9.7 \%$ of these individuals presented periodontal pockets ${ }^{10}$. In this way, injuries caused by these oral diseases could interfere in academic activities and performance ${ }^{11}$. Although literature presents some studies evaluating the oral health and associated factors in university students, mostly are cross-sectional studies ${ }^{6,12-16}$ and few presented longitudinal design ${ }^{17}$, which could investigated the influence and the changes occurs throughout the academic life of these populations. Thus, the aim of this paper was to describe the methodological aspects in the baseline of university students' cohort in a public university in southern Brazil.

\section{Materials and methods}

This multidisciplinary cohort study assessed the psychosocial and oral health conditions of new academics of 2016 university students in Pelotas. This is the first part (the baseline with a cross-sectional design) of a longitudinal study that will follow up university students throughout their academic trajectory.

\section{Baseline}

\section{Sampling procedure}

All individual who university students who have entered in 2016 year at the UFPel were initially eligible for the study. As inclusion criteria, these new academic students should be properly enrolled in the first semester, of any classroom-based course offered by the institution, after a selection process performed in the previous year. Repeat students of the first semester of any academic course who have entered at the University in other year and those who were not able to self-answer the questionnaire were not included. 
Currently, above 18,000 undergraduate students are enrolled in the UFPel. Each year, approximately 3,000 students are selected to join the institution. Considering the estimated number of entrants in the first semester of 2016 (3000 students) and a prevalence of $50 \%$ for the variables of interest, a frequency estimation accuracy of 1.8 percentage points was obtained within a $95 \%$ confidence interval. For association analysis, this sample size is sufficient to detect a prevalence ratio of 1.4 , considering a prevalence of exposure of $50 \%$, prevalence of outcome in exposed individuals of $5 \%$, power of $80 \%$, and $a=5 \%$. Therefore, the minimum sample size estimated was of 614 individuals. In addition, in order to maintain the proportionality of the data collected, we considered that at least $60 \%$ of the students in each course should be interviewed, taking in count the number of matriculated students in respective courses. Each course was visited until achieve the minimal sample size of $60 \%$ of total students.

\section{Logistic}

Before data collection, it was performed a mapping of all academic units belonging to the university and their respective coordinators. All academic units were informed about the study and authorized its accomplishment. An initial visit was made by supervisors to all schools of the University to obtain authorization of coordinators of each undergraduate course. Previously to data collection, all students were invited to participate receiving an information letter about the study and those who accepted have signed an informed consent form. Participants under 18 years of age received a consent form to be given to those responsible. Those responsible who lived in another city, an online consent form was sent to the email available by the student. Failure to receive the informed consent form from responsible was one of the exclusion criteria of final sample.

In order to reduce possible losses in the next follow-ups, some measures were adopted. Two researchers blinded to previous steps in data collection, identified the enrollment number at the institution of each student from the full name presented in the first questionnaire. The enrollment number was matched with the identification number of the questionnaire. Thus, a specific database for the identification of these students in future follow-ups was created. At the end of each year, these same researchers will update the situation in the institution of the students. With prior authorization of the university sector responsible for enrollment, lockouts and course's transfers of students, this information will be collected from the institution's student database.

\section{Data collection}

Data collection was scheduled with the professor previously recommended by coordinator of each school. After signing the consent form, two self-administered questionnaires previously tested were applied in classroom during class time: one general and one confidential. The first questionnaire was identified by the student's name accompanied by an identification number (ID). The second questionnaire was identified only for the ID. Students were instructed to deposit the general questionnaire attached to the consent term in a specific folder and the confidential questionnaire in a sealed carton box. 


\section{General interview}

The first questionnaire had 74 questions divided into 4 blocks. More details are presented in Figure 1. The first block included questions about socioeconomic characteristics. Age, gender, nationality and city of birth, skin color (according to Brazilian Institute of Geography and Statistics - IBGE - white, brown, black, yellow, Indian) ${ }^{18}$, parental' schooling (father and mother) (no study, incomplete elementary school, complete elementary school, incomplete high school, complete high school, incomplete university, complete university), marital status (single, married, divorced, widow, common-law marriage), employment status (employed/no employed), and family income were collected. The income was measured in Brazilian Reais (BRL): (a) up to 500.00 ; b) 5001.00 up to $1,000.00$; c) $1,001.00$ up to $2,500.00$; d) $2,501.00$ up to $5,000.00$; e) $5,001.00$ up to $10,000.00$; and f) more than $10,001.00$. Information about family structure (main provider of family income) and number of persons living in a household was also collected. Information about high school (private or public) and the need for preparatory course (private or public) for university entrance were collected. Students were also questioned about the need for some financial University assistance during graduation, e.g. using University house or receiving financial aid to rent a share apartment, or having the intention to request that. The students were also asked if they would like to for scientific initiation scholarship. In relation to the undergraduate course, it was questioned if previously they had already attended to another university course, if the current course was their first choice, and the reasons for that choice, such as family influence, expected financial return, job market or personal expectations.

The second block was related to psychosocial and behavioral characteristics. Perception of happiness, depression, stress, dental fear and dental anxiety were the psychosocial data collected. The perception of happiness was measured by a question accompanied of the faces scale of Andrews and Whitey modified by McDowell and Newell ${ }^{19}$. Depression was assessed by the Patient Health Questionnaire-2 (PHQ-2) (20), an abbreviated version of the Patient Health Questionnaire Depression (PHQ-9) ${ }^{20}$ used for depression screening ${ }^{21}$. The stress' level was measured using a modified version of the Perceived Stress Scale (PSS) ${ }^{22}$. Dental fear was assessed by the Dental Anxiety Question (DAQ) ${ }^{23}$ and dental anxiety was measured using a modified version of the Dental Anxiety Scale (M-DAS) ${ }^{24}$.

The third block presented self-reported questions related to oral health behaviors. This choice was adopted due to high cost and time spent to perform oral clinical evaluation. In relation to dental service use, questions regarding to the last time of dental visit and the reasons for that, as well as type of dental service (private or public) applied. Dental aesthetics was assessed through questions about self-perception of oral health, satisfaction with both dental color and dental appearance, desire to perform some aesthetic dental treatment, and performing tooth whitening.

The fourth block was about oral health-related quality of life (OHRQOL) and oral health self-reported measures. The OHRQOL was measured using the Oral Impacts Daily Performance (OIDP) ${ }^{25}$. In order to estimate presence of oral health diseases, presence of dental caries ${ }^{26}$, history of tooth extraction and dental restoration, presence of dental bleeding ${ }^{27}$, temporomandibular dysfunction ${ }^{28}$, bruxism and halitosis ${ }^{29}$ 
were collected. Presence of dental pain in the last six months and its intensity was also assessed. The intensity of dental pain was measured in a scale ranging from zero to 10 points.

\section{Confidential interview}

A second questionnaire was specific to the use of alcohol, tobacco and illicit drugs. This questionnaire was codified presenting the same identification number that the first questionnaire, without the full name of students. For this purpose, a Brazilian validated of the Alcohol, Smoking and Substance Involvement Screening Test (ASSIST) recommended by the World Health Organization $(\mathrm{WHO})$ was used ${ }^{30}$. The first question investigated the types of drugs used by the person. The second question assessed whether the person has ever tried to control, reduce or stop drug use. If the answer was yes, it was asked whether the person was able to stop drug use. The following two questions were related to the last three months and address the issues of the frequency of drug use, and the occurrence of some social, physical, financial, legal or personal problems caused by the drug use. The last two questions were related to the amount of tobacco and alcohol consumed daily, respectively. The response alternatives were presented in a 6-points Likert scale with the following answer options: "never", "once or twice", "monthly", "weekly", "daily or almost every day".

\section{Theoretical and practical training}

A four-hour theoretical training was performed. Supervisors presented the two questionnaires. The field team (25 individuals) also discussed each question and clarified possible doubts or difficulties in the understanding of the university students.

A pilot study was conducted with 100 university students $(n=100)$ of second semester of undergraduate school, not eligible for the study, from five different academic units randomly selected.

\section{Ethical aspects}

This study was approved by the Human Ethics Research Committee of the School of Medicine at Federal University of Pelotas (protocol number 49449415.2.0000.5317).

\section{Future follow-up}

The first follow-up of this study is planned to be performed in the second semester of 2019 year. As a first step, the directory of academic records will be contacted in order to identify the academic status at the university of each research participant. Through the student's names, collected in the baseline, it will be possible to access the institutional database of UFPel, where each individual presents a code (regardless of whether they have changed or abandoned the faculty). Therefore, all students included in the present study will be identified even in cases of faculty change or in cases where students lockout the academic activities in UFPel. Thus, individuals who will not be initially identified in their respective classes will be searched via email and/or individually. In this way, a greater number of students could be accessed. In order to ensure that the same student will be interviewed, a single researcher will prepare a list of the identification numbers with their respective name of participants 
for each course. During the collection data of the follow-up, the questionnaires will be delivered according to the identification number.

Several variables collected in the baseline will be again collected.

Variables collected in the baseline and those possibly to be collected in the first follow-up are presented in the Figure 1. We expect small changes in oral health conditions since the period between follow-ups is short and chronic diseases such as dental caries and periodontal disease require longer periods to observe significant differences. In addition, behavioral and psychological issues may be strongly influenced by the semester (eg, beginning, middle, and end of semester). In this way, the first follow up will be (as the baseline) carried out at the beginning of the semester so that the data have smaller distortions.

\section{Data analysis}

Data were double entered into an Excel Office (Microsoft Office) database. In order to detect possible mistakes, automatic checks for consistency range and valida-

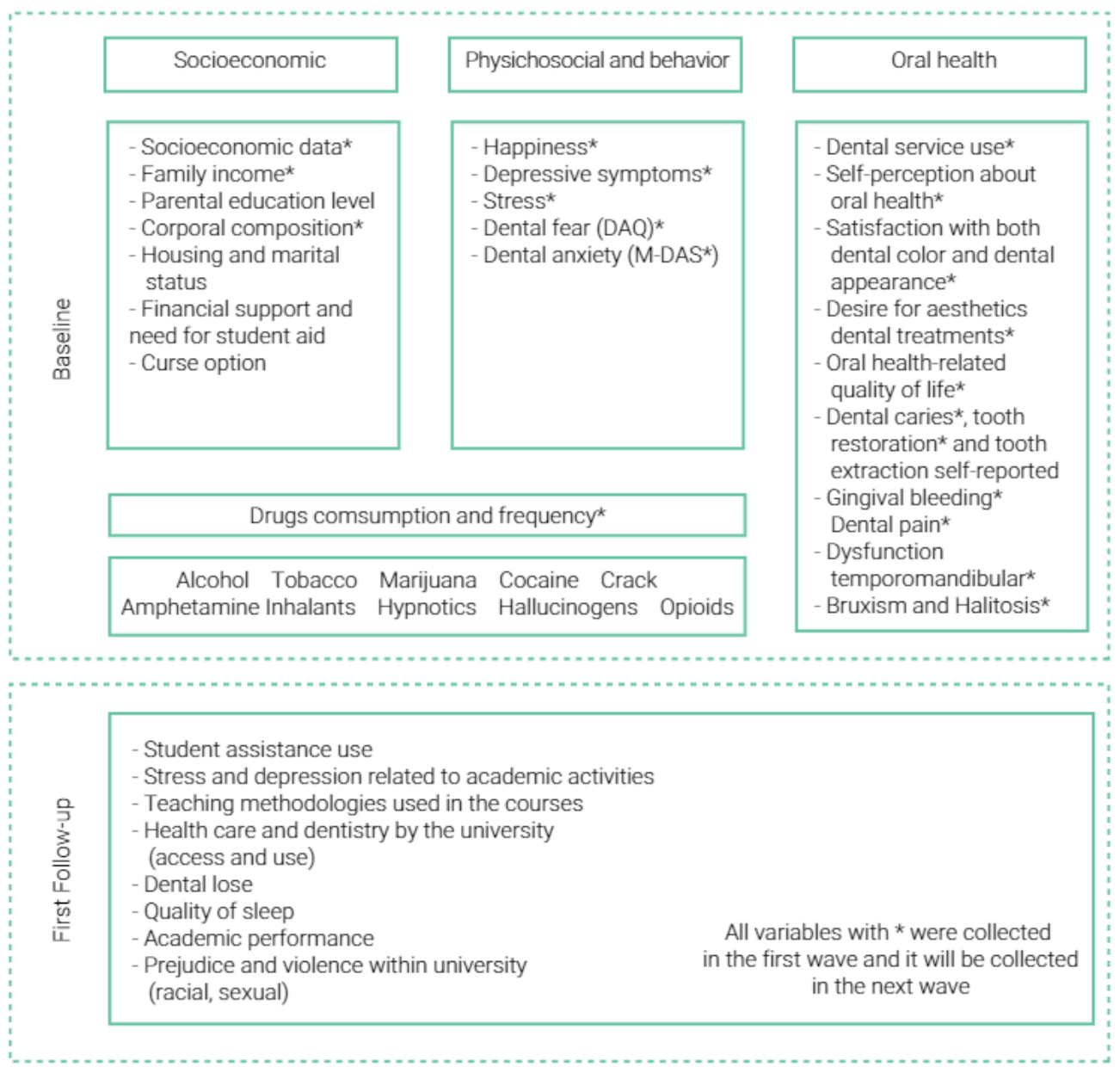

Figure 1. Data collected during the survey (baseline) and variables that will be investigated in first follow-up. 
tion of duplicate files was performed. Data analysis was carried out using Stata 14.0 (Stata Corp., College Station, USA). Descriptive statistics were used to characterize the sample.

\section{Results}

After the pilot study, the questionnaire was adjusted to facilitate participants' understanding. An average time of 20 minutes (ranging from 15 to 40 minutes) for completing the instrument was estimated. Figure 2 shows the flowchart of the baseline of study. An overall of 3,577 students entered in the Federal University of Pelotas in 2016. At the end of 2016, the loss rate was estimated at $9.5 \%$ (340 students). Thereby, 3,237 students were considered eligible. Of these, 2,089 (64.5\%) signed the consent form to participate of the study and answered the general questionnaires and 2,052 (63.4\%) answered the confidential questionnaire. The mainly reason for loss was the low classrooms frequency of students, who did not found after three searches in the classroom. Refuses represented only $1.4 \%$ of total students invited to participle. Students that did not found in the respective classes were considered as losses (34.6\%). Figure 3 shows the distribution of included participants by courses and knowledge areas.

About $44 \%$ of the surveyed students were natural from Pelotas, with $81.1 \%$ born in the State of Rio Grande do Sul. Only $0.5 \%$ of the students were not Brazilians. An important part of students (30\%) reported that the course they were attending were not their first choice. Table 1 shows the description of general characteristics of sample. In some cases, data regarding certain characteristics was missed because the students failed to complete the entire questionnaire.

PILOT

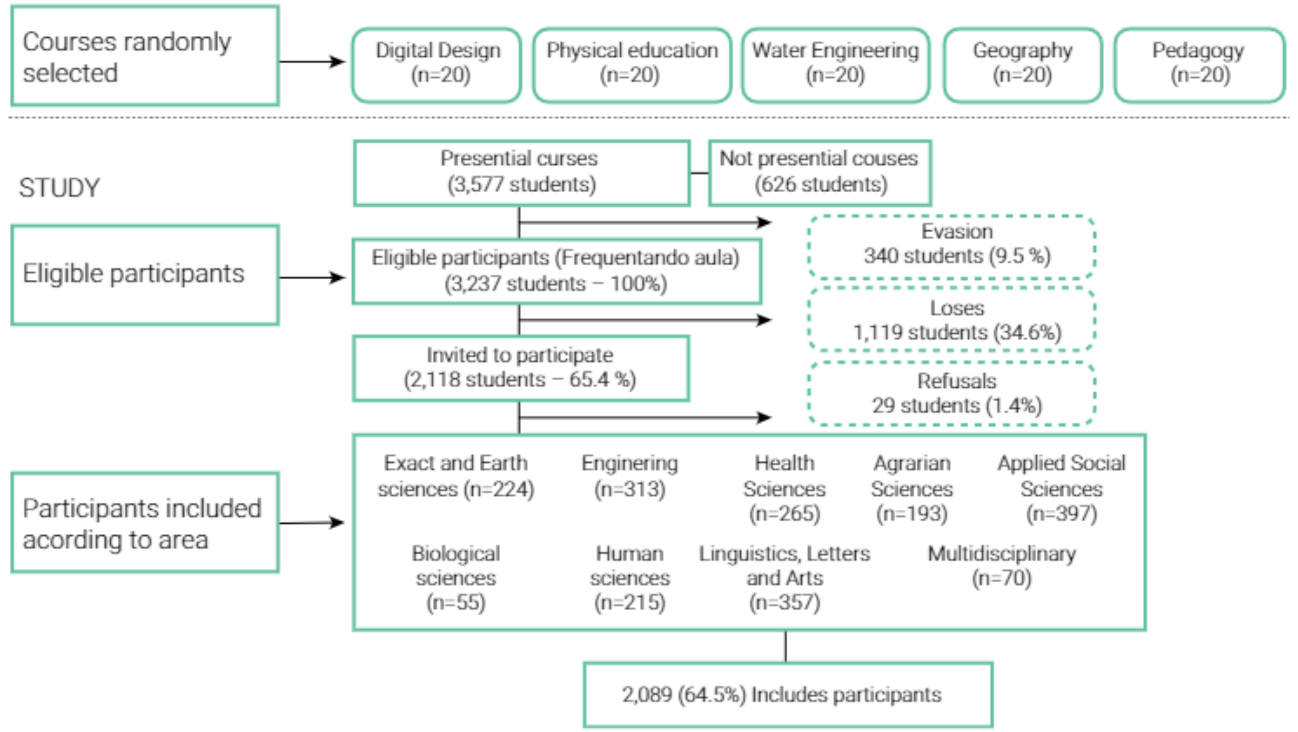

Figure 2. Flowchart of the study. 


\begin{tabular}{|c|c|c|c|c|}
\hline $\begin{array}{c}\text { Exact and } \\
\text { Earth sciences } \\
(10.7 \%)\end{array}$ & $\begin{array}{l}\text { Enginering } \\
\text { (15\%) }\end{array}$ & $\begin{array}{l}\text { Health } \\
\text { Sciences } \\
(12.7 \%)\end{array}$ & $\begin{array}{c}\text { Agrarian } \\
\text { Sciences } \\
(9.2 \%)\end{array}$ & $\begin{array}{l}\text { Applied Social } \\
\text { Sciences (19\%) }\end{array}$ \\
\hline $\begin{array}{l}\text { - Computer Science (33) } \\
\text { - Physics (38) } \\
\text { - Geoprocessing (21) } \\
\text { - Mathematics (43) } \\
\text { - Weather } \\
\text { (METEOROLOGIA) (20) } \\
\text { - Chemistry (45) } \\
\text { - Food Chemistry (24) }\end{array}$ & $\begin{array}{l}\text { - Environmental } \\
\text { Engineeriing (30) } \\
\text { - Civil lengineering (25) } \\
\text { - Computer engineering (32) } \\
\text { - Control and automation } \\
\text { engineering (16) } \\
\text { - Materials Engineering (28) } \\
\text { - Petroleum Engineering (16) } \\
\text { - Production Engineering (33) } \\
\text { - Electronic Engineering (33) } \\
\text { - Geological Engineering (42) } \\
\text { - Water Engineering (30) } \\
\text { - Industrial Engineering (28) }\end{array}$ & $\begin{array}{l}\text { - Physical Education (79) } \\
\text { - Nursing (46) } \\
\text { - Medicine (46) } \\
\text { - Nutrition (41) } \\
\text { - Dentistry (53) }\end{array}$ & $\begin{array}{l}\text { - Agronomy (77) } \\
\text { - Agricultural } \\
\text { engineering (27) } \\
\text { - Veterinary Medicine (56) } \\
\text { - Animal Husbandry (28) }\end{array}$ & $\begin{array}{l}\text { - Administration (25) } \\
\text { - Architecture and } \\
\text { Urbanism (25) } \\
\text { - Economic sciences (29) } \\
\text { - Conservation and } \\
\text { restoration (33) } \\
\text { - Law (75) } \\
\text { - Environmental } \\
\text { Management (30) } \\
\text { - Public administration (32) } \\
\text { - Hospitality (14) } \\
\text { - Journalism (34) } \\
\text { - Museology (21) } \\
\text { - Management Processes (44) } \\
\text { - Tourism (35) }\end{array}$ \\
\hline $\begin{array}{l}\text { Biological } \\
\text { sciences } \\
(2.6 \%)\end{array}$ & $\begin{array}{l}\text { Human } \\
\text { sciences } \\
(10.3 \%)\end{array}$ & $\begin{array}{l}\text { Linguistics, } \\
\text { Letters and } \\
\text { Arts (10.3\%) }\end{array}$ & $\begin{array}{c}\text { Multidisciplinary } \\
(3.4 \%)\end{array}$ & \\
\hline - Biological sciences (55) & $\begin{array}{l}\text { - Anthropology and } \\
\text { Archeology (28) } \\
\text { - Social sciences (51) } \\
\text { - Gegraphy (44) } \\
\text { - History (39) }\end{array}$ & $\begin{array}{l}\text { - Visual Arts (62) } \\
\text { - Cinema and animation (18) } \\
\text { - Cinema and audiovisual (20) } \\
\text { - Graphic Design (22) } \\
\text { - Lyrics (93) } \\
\text { - Music (65) } \\
\text { - Pedagogy (36) } \\
\text { - Theater (14) }\end{array}$ & $\begin{array}{l}\text { - Biotechnology (30) } \\
\text { - International Relations (4) }\end{array}$ & \\
\hline
\end{tabular}

Figure 3. Participants included in the study according to their course and respective knowledge area $(n=2,089)$.

\section{Discussion}

The present paper details the methodology of a university students' cohort who entered a public university in southern Brazil in 2016. Psychosocial, behavioral and self-reported data of oral health were collected. Although some studies have evaluated some specific topic in university students ${ }^{31-33}$, to best of our knowledge, this is the first university student's cohort, which will evaluate a wide range of issues, including oral health aspects, in this population, besides to be designed to evaluate prospectively the students during the undergraduate period.

University students present different characteristics from general population and, therefore, must be also considered in the epidemiological studies. Overall, these individuals presented a young age (late adolescence and early adulthood) and are in a period of life characterized by significant changes ${ }^{34-36}$. In this context, adolescents and young adults still are in profound development of Ego and the family context seems to be extremely important to contribute promoting the individual growth ${ }^{3}$. These changes are added to psychological modifications because they are still building up their personality, which could be influenced by changes in life habits and could have a tend to remain for their latter periods of life ${ }^{3}$.

One of the behavior changes observed in this period of life is related to the freedom sensation, since a part of these youngers move away from family and start to live with their colleagues ${ }^{37,38}$. Moreover, autonomy itself, because it is a university, could favor the change of these habits, since less control on the part of the institution is exerted on the students when compared to the high school. In this way, some studies have found that university students presented a higher consumption of alcohol, tobacco 
Table 1. Description of the general characteristics of the sample $(n=2089)$.

\begin{tabular}{|c|c|}
\hline Variable/Category & Total Sample* -- n (\%) \\
\hline \multicolumn{2}{|l|}{ Socioeconomic data } \\
\hline $\begin{array}{l}\text { Sex } \\
\quad \text { Female } \\
\text { Male }\end{array}$ & $\begin{array}{c}2080 \\
1,087(52.2) \\
993(47.7) \\
\end{array}$ \\
\hline $\begin{array}{l}\text { Age (years) } \\
\begin{array}{l}16 \text { to } 17 \\
18 \text { to } 24 \\
25 \text { to } 34 \\
35 \text { or more }\end{array}\end{array}$ & $\begin{array}{c}2080 \\
312(15.0) \\
1,375(66.1) \\
215(10.3) \\
178(8.6)\end{array}$ \\
\hline $\begin{array}{l}\text { Skin Color } \\
\text { White } \\
\text { Black } \\
\text { Brown } \\
\text { Yellow } \\
\text { Amerindian }\end{array}$ & $\begin{array}{c}2045 \\
1,515(74.1) \\
172(8,4) \\
336(16,4) \\
15(0,73) \\
7(0,3)\end{array}$ \\
\hline $\begin{array}{l}\text { Family income } \\
\quad \leq 1000 \\
\quad 1001 \text { to } 5000 \\
\geq 5001\end{array}$ & $\begin{array}{c}1717 \\
280(16.3) \\
1,057(61.6) \\
380(22.1)\end{array}$ \\
\hline $\begin{array}{l}\text { Maternal schooling } \\
\text { Elementary school incomplete } \\
\text { Elementary school } \\
\text { High school } \\
\text { University }\end{array}$ & $\begin{array}{c}\mathbf{2 0 5 8} \\
470(22.8) \\
272(13.2) \\
649(31.5) \\
667(32.4)\end{array}$ \\
\hline $\begin{array}{l}\text { Financial Support } \\
\text { Parents } \\
\text { Own } \\
\text { Other }\end{array}$ & $\begin{array}{c}2056 \\
1,585(77.0) \\
349(17.0) \\
122(06.0) \\
\end{array}$ \\
\hline $\begin{array}{l}\text { Dwelling } \\
\text { Parents } \\
\text { Alone } \\
\text { Spouse / partner } \\
\text { Other }\end{array}$ & $\begin{array}{c}2064 \\
876(42.4) \\
305(14.8) \\
255(12.4) \\
328(25.2) \\
\end{array}$ \\
\hline $\begin{array}{l}\text { High school type } \\
\text { Public } \\
\text { Private and public } \\
\text { Private }\end{array}$ & $\begin{array}{c}2,085 \\
1,425(68.3) \\
148(7.1) \\
512(24.6)\end{array}$ \\
\hline $\begin{array}{l}\text { Preparatory course } \\
\text { No } \\
\text { Yes }\end{array}$ & $\begin{array}{c}2,084 \\
1,246(59.8) \\
838(40.2)\end{array}$ \\
\hline $\begin{array}{l}\text { First option curse } \\
\text { Yes } \\
\text { No }\end{array}$ & $\begin{array}{c}\mathbf{2 , 0 7 8} \\
1,472(70.8) \\
606(29.2)\end{array}$ \\
\hline $\begin{array}{l}\text { Other graduation } \\
\text { No } \\
\text { Yes, without finishing } \\
\text { Yes, finished }\end{array}$ & $\begin{array}{c}\mathbf{2 , 0 8 0} \\
1,450(69.7) \\
439(21.1) \\
191(9.2)\end{array}$ \\
\hline
\end{tabular}

* Different sample are due to missing on data collection

and illicit drugs ${ }^{39-41}$. Similarly, the use of pharmacological substances with the aim of to increase the cognitive capacity is frequently reported among these students ${ }^{42-44}$. Environments where a high cognitively capacity is demanded, like in the Universities, can provide the appropriate place where stimulant drugs start to be used, with the aim to increase the concentration ability and reasoning ability ${ }^{45}$. All these factors can be 
added to the relationship between the individual maturity and independency, in a new environment with high academic collection imposed by the university.

In order to increase the response's rate of questions related to the use of alcohol, tobacco and illicit drugs, a confidential questionnaire was performed. Both questionnaires (general and drugs) were numerically encoded and delivered to the students, which only filled the name in the general questionnaire. The full name and electronic address were asked to facilitate posterior identification of these students in the future waves of this cohort. Moreover, questionnaires were collected separately. The general questionnaire was deposited in a specific folder for this, attached with the consent term, while the confidential questionnaire was placed in a sealed carton box. Each confidential questionnaire was linked to an identification number, which was also presented in the general questionnaire, ensuring the confidentiality of information collected. The response rate for this questionnaire was relatively high and could be considered as an interesting strategy in themes addressing particular issues that could cause some kind of embarrassment. Therefore, the separated questionnaires can increase the adhesion of participants to report particular issues.

We have selected an obligatory discipline in the first semester in agreement of each course coordinator and the professor responsible for the discipline. A disadvantage of logistic employed in this study is the possibility of loss of absent students in the class in the day scheduled by the staff. Despite that, the strategy of contacting the course coordinator to request the target discipline and then to contact with the Professor responsible for the discipline in order to conduct the interviews in a day with important activities (and consequent high level of presents) seems to have helped to reduce the number of losses. Thus, this methodology was adopted because it was easier to find the major part of the students in the same local.

Oral health conditions were measured using self-perception questions. Even though, self-perception is a subjective parameter, there are several studies using the self-reporting as a manner to obtain the information ${ }^{46-53}$. Researches have shown a consistent agreement among the self-report and clinical examination for caries and tooth-loss $26,46,54$. Therefore, in cases where clinical examination may not be feasible, the use of self-reporting tools could be a reliable alternative for oral health evaluation, being an efficient and simple method, with a low cost, and reducing the time of examination $29,55,56$. The oral health self-reported instruments are a valid tool and have shown high reproducibility. Besides are important tools to evaluated oral outcomes mainly in studies that also investigated the psychological exposition $25,47,57$. In the next follow-up, we plan to conduct the oral examination of a representative sample of students. In the baseline we chose to use measures of self-report due to the lack of funds for the clinical exams and the short time we had to collect the data

Besides the socioeconomic, psychosocial, behavioral and oral health self-report variables, we will be evaluating the academic performance of the students during their course, which will be carried out in the next cohort wave. Therefore, we will be able to investigate factors that influence the performance of students. We had already planned a second wave, which will be performed in 2019 year. Furthermore, there is a possibility of a third wave be performed aim to assess those university students who belong to faculties with graduation time greater than four years. We are plan- 
ning more one wave of assessment middle/final of the course. In general, the graduate courses in Brazilian presents 4 to 5 years. However, some courses present only 3 years, because this, the second wave will be in the third year of the baseline. With a prospective study, i.g cohort, is possible to identify potential risk factors related to health and those that may influence the academic performance during the undergraduate life. In fact, with the name of students collected in the baseline, we will identify the students and search them in their respective academic units or in the Institution unified enrollment system and they will answer a questionnaire.

Noteworthy, the sample of this study presents different characteristics of the general population with similar age that is not enrolled in universities, such as the socioeconomic level. Therefore, the extrapolation of the data obtained in this study is not possible to the general population, not even for private universities. Indeed, despite the improvement in the last few years, with a higher number of individuals entering in the Universities and with the introduction of social and ethnic quotes increasing the diversity in the university environment, the access to University is still reduced in Brazil|58. As observed in our results, the population attending to the University is still in the majority from higher socioeconomic level ${ }^{58}$.

Moreover, the critical point to cohort study is the monitoring of the sample to the period between the follow-ups, which requires great attention and care, raising the costs to develop this type of study. Efforts in this regard have been undertaken by researchers to prevent a high number of losses in the first follow-up. Thus, the closer ties between the administrative part of the institution has been a fundamental point for the possibility of the present study to monitoring the register of students. Besides that, the project of this study was submitted to financial statements in order to have the financial resources to carry out the first follow-up with the accomplishment of clinical exams. Unfortunately, the lack of financial support has prevented us from conducting clinical exams, and has therefore opted for subjective measures, which are widely used in epidemiological studies.

To the knowledge of researchers, this was the first cohort study of university students in the South of Brazil including more than two thousand participants. This study emphasizes the importance of investigation of psychosocial, behavioral and oral health self-report measures for university students by means of a cohort design. The method used by this study will allow investigators to obtain data of several different health outcomes and on possible risk factors related to general and oral health as well as academic performance. The strategy adopted to optimize the study were descripted to help to allow us to evaluate the applicability of our methods for application in other research questions and planning epidemiological studies in similar populations. Thus, the use of confidential questionnaires codified aim to increase the responses of licit and illicit drugs as well as theoretical and practical training and test of the questionnaires were approach improved the quality of study.

\section{References}

1. Andrade EC. Quotas in Brazilian public universities: good or bad idea? Rev Bras Econ. 2004 Oct/ Dec;58(7):453-84. doi: 10.1590/S0034-71402004000400001. 
2. INEP. National Institute for Educational Studies and Research "Anísio Teixeira". [National Student Performance Exam]. Brasília: INEP; 2017 [cited 2019 Jan 12]. Avaiable fron: http://portal.inep.gov.br/ enade. Portuguese.

3. Syed M, Seiffge-Krenke I. Personality development from adolescence to emerging adulthood: linking trajectories of ego development to the family context and identity formation. J Pers Soc Psychol. 2013 Feb;104(2):371-84. doi: 10.1037/a0030070.

4. Billings RL, Hauser ST, Allen JP. Continuity and Change from Adolescence to Emerging Adulthood: Adolescence-limited vs. Life-course-persistent Profound Ego Development Arrests. J Youth Adolesc. 2008 Nov;37(10):1178-1192. doi: 10.1007/s10964-008-9317-4.

5. Haberman S, Luffey D. Weighing in college students' diet and exercise behaviors. J J Am Coll Health. 1998 Jan;46(4):189-91.

6. Freire M, Martins A, Santos C, Martins N, Filizzola E, Jordão L, et al. [Oral health status, behaviours, self-perception and associated impacts among university students living in student residences]. Rev Odontol UNESP. 2012;41(3):185-91. doi: 10.11606/s1518-8787.2018052000361. Portuguese.

7. Marcenes W, Kassebaum NJ, Bernabe E, Flaxman A, Naghavi M, Lopez A, et al. Global burden of oral conditions in 1990-2010: a systematic analysis. J Dent Res. 2013 Jul;92(7):592-7. doi: $10.1177 / 0022034513490168$.

8. Lambert MJ, Vanobbergen JSN, Martens LC, De Visschere LMJ. Socioeconomic inequalities in caries experience, care level and dental attendance in primary school children in Belgium: a cross-sectional survey. BMJ Open. 2017 Jul 20;7(7):e015042. doi: 10.1136/bmjopen-2016-015042.

9. de Silva AM, Hegde S, Akudo Nwagbara B, Calache H, Gussy MG, Nasser M, et al. WITHDRAWN: Community-based population-level interventions for promoting child oral health. Cochrane Database Syst Rev. 2016 Dec 22;12:CD009837. doi: 10.1002/14651858.CD009837.pub3.

10. Ministry of Health. Md health. [SB Brazil Project 2010. Oral health conditions of the Brazilian population: main results]. Brasília: Ministry of Health; 2012. Portuguese.

11. Jackson SL, Vann WF, Jr., Kotch JB, Pahel BT, Lee JY. Impact of poor oral health on children's school attendance and performance. Am J Public Health. 2011 Oct;101(10):1900-6. doi: 10.2105/AJPH.2010.200915.

12. Tucktuck M, Ghandour R, Abu-Rmeileh NME. Waterpipe and cigarette tobacco smoking among Palestinian university students: a cross-sectional study. BMC Public Health. 2017 Jul 10;18(1):1. doi: 10.1186/s12889-017-4524-0.

13. Yamane-Takeuchi M, Ekuni D, Mizutani S, Kataoka K, Taniguchi-Tabata A, Azuma T, et al. Associations among oral health-related quality of life, subjective symptoms, clinical status, and self-rated oral health in Japanese university students: a cross-sectional study. BMC Oral Health. 2016 Nov;16(1):127.

14. Pohjola V, Rekola A, Kunttu K, Virtanen JI. Association between dental fear and oral health habits and treatment need among University students in Finland: a national study. BMC Oral Health. 2016 Feb 27;16:26. doi: 10.1186/s12903-016-0179-y.

15. Alsumait A, EISalhy M, Amin M. Long-Term Effects of School-Based Oral Health Program on Oral Health Knowledge and Practices and Oral Health-Related Quality of Life. Med Princ Pract. 2015;24(4):362-8. doi: 10.1159/000430096.

16. Obeidat SR, Khabour OF, Alzoubi KH, Mahasneh AM, Bibars AR, Khader YS, et al. Prevalence, social acceptance, and awareness of waterpipe smoking among dental university students: a cross sectional survey conducted in Jordan. BMC Res Notes. 2014;7:832. doi: 10.1186/1756-0500-7-832.

17. Akhter R, Morita M, Esaki M, Nakamura K, Kanehira T. Development of temporomandibular disorder symptoms: a 3-year cohort study of university students. J Oral Rehabil. 2011 Jun;38(6):395-403. doi: 10.1111/j.1365-2842.2010.02195.x. 
18. IBGE. [Brazilian Census 2000]. Rio de Janeiro: Brazilian Institute of Geography and Statistics; 2001. Report No. 1. Portuguese.

19. McDowell I, Newell C. Measuring health: a guide to rating scales and questionnaires. 3. ed. New York: Oxford University Press; 1996. p.765.

20. Arroll B, Goodyear-Smith F, Crengle S, Gunn J, Kerse N, Fishman T, et al. Validation of PHQ-2 and PHQ-9 to screen for major depression in the primary care population. Ann Fam Med. 2010 Jul-Aug;8(4):348-53. doi: 10.1370/afm.1139.

21. Kroenke K, Spitzer RL, Williams JB. The Patient Health Questionnaire-2: validity of a two-item depression screener. Med Care. 2003 Nov;41(11):1284-92.

22. Cohen S, Kamarck T, Mermelstein R. A global measure of perceived stress. J Health Soc Behav. 1983 Dec;24(4):385-96.

23. Neverlien PO. Dental anxiety, optimism-pessimism, and dental experience from childhood to adolescence. Community Dent Oral Epidemiol. 1994 Aug;22(4):263-8.

24. Kyritsi MA, Dimou G, Lygidakis NA. Parental attitudes and perceptions affecting children's dental behaviour in Greek population. A clinical study. Eur Arch Paediatr Dent. 2009 Jan;10(1):29-32.

25. Cortes MI, Marcenes W, Sheiham A. Impact of traumatic injuries to the permanent teeth on the oral health-related quality of life in 12-14-year-old children. Community Dent Oral Epidemiol. 2002 Jun;30(3):193-8.

26. Silva AE, Menezes AM, Assuncao MC, Goncalves H, Demarco FF, Vargas-Ferreira F, et al. Validation of self-reported information on dental caries in a birth cohort at 18 years of age. PLoS One. 2014 Sep 9;9(9):e106382. doi: 10.1371/journal.pone.0106382.

27. Baser U, Germen M, Erdem Y, Issever H, Yalcin F. Evaluation of gingival bleeding awareness by comparison of self-reports and clinical measurements of freshman dental students. Eur J Dent. 2014 Jul;8(3):360-5. doi: 10.4103/1305-7456.137649.

28. Gonzalez YM, Schiffman E, Gordon SM, Seago B, Truelove EL, Slade G, et al. Development of a brief and effective temporomandibular disorder pain screening questionnaire: reliability and validity. J Am Dent Assoc. 2011 Oct;142(10):1183-91.

29. Rosenberg M, Kozlovsky A, Gelernter I, Cherniak O, Gabbay J, Baht R, et al. Self-estimation of oral malodor. J Dent Res. 1995 Sep;74(9):1577-82.

30. Henrique I, Micheli D, Roseli Boerngen de Lacerda R, Lacerda L, Formigoni M. [Validation of the Brazilian version of Alcohol, Smoking and Substance Involvement Screening Test (ASSIST)]. Rev Assoc Med Bras (1992). 2004 Apr-Jun;50(2):199-206. Portuguese.

31. Saito M, Ando-Tanabe N, Arita E. Factors associated with medication amounts considered excessive among university students: a questionnaire survey of pharmacy students and those in non-medical schools. BMC Health Serv Res. 2017 Jul 11;17(1):475. doi: 10.1186/s12913-017-2431-9.

32. Gulec Oyekcin D, Sahin EM, Aldemir E. Mental health, suicidality and hopelessness among university students in Turkey. Asian J Psychiatr. 2017 Oct;29:185-189. doi: 10.1016/j.ajp.2017.06.007.

33. Oksanen A, Laimi K, Bjorklund K, Loyttyniemi E, Kunttu K. A 12-year Trend of Psychological Distress: National Study of Finnish University Students. Cent Eur J Public Health. 2017 Jun;25(2):113-119. doi: $10.21101 /$ cejph.a4438.

34. Ludtke O, Roberts BW, Trautwein U, Nagy G. A random walk down university avenue: life paths, life events, and personality trait change at the transition to university life. J Pers Soc Psychol. 2011 Sep;101(3):620-37. doi: 10.1037/a0023743.

35. Simons D, Rosenberg M, Salmon J, Knuiman M, Granich J, Deforche B, et al. Psychosocial moderators of associations between life events and changes in physical activity after leaving high school. Prev Med. 2015 Mar;72:30-3. doi: 10.1016/j.ypmed.2014.12.039 
36. Deforche B, Van Dyck D, Deliens T, De Bourdeaudhuij I. Changes in weight, physical activity, sedentary behaviour and dietary intake during the transition to higher education: a prospective study. Int $\mathrm{J}$ Behav Nutr Phys Act. 2015 Feb 15;12:16. doi: 10.1186/s12966-015-0173-9.

37. Vansteenkiste M, Soenens B, Van Petegem S, Duriez B. Longitudinal associations between adolescent perceived degree and style of parental prohibition and internalization and defiance. Dev Psychol. 2014 Jan;50(1):229-36. doi: 10.1037/a0032972.

38. Sher-Censor E, Parke RD, Coltrane S. Parents' promotion of psychological autonomy, psychological control, and Mexican-American adolescents' adjustment. J Youth Adolesc. 2011 May;40(5):620-32. doi: 10.1007/s10964-010-9552-3.

39. Kolsek M, Klemenc Ketis Z. Alcohol Drinking Among the Students of the University of Maribor, Slovenia. Zdr Varst. 2015 Sep 25;54(4):259-66. doi: 10.1515/sjph-2015-0034.

40. Lauritsen KJ, Rosenberg H, Sprague JE. University students' attributions for abstinence from synthetic cannabinoids and synthetic cathinones. Am J Drug Alcohol Abuse. 2018;44(1):64-72. doi: 10.1080/00952990.2017.1289214.

41. Vatovec C, Van Wagoner E, Evans C. Investigating sources of pharmaceutical pollution: Survey of over-the-counter and prescription medication purchasing, use, and disposal practices among university students. J Environ Manage. 2017 Aug 1;198(Pt 1):348-352. doi: 10.1016/j.jenvman.2017.04.101.

42. Schelle KJ, Olthof BM, Reintjes W, Bundt C, Gusman-Vermeer J, van Mil AC. A survey of substance use for cognitive enhancement by university students in the Netherlands. Front Syst Neurosci. 2015 Feb 17;9:10. doi: 10.3389/fnsys.2015.00010.

43. Singh I, Bard I, Jackson J. Robust resilience and substantial interest: a survey of pharmacological cognitive enhancement among university students in the UK and Ireland. PLoS One. 2014 Oct 30;9(10):e105969. doi: 10.1371/journal.pone.0105969.

44. Hildt E, Lieb K, Franke AG. Life context of pharmacological academic performance enhancement among university students-a qualitative approach. BMC Med Ethics. 2014 Mar 7;15:23. doi: 10.1186/1472-6939-15-23.

45. Smith ME, Farah MJ. Are prescription stimulants "smart pills"? The epidemiology and cognitive neuroscience of prescription stimulant use by normal healthy individuals. Psychol Bull. 2011 Sep;137(5):717-41. doi: 10.1037/a0023825.

46. Thomson WM, Mejia GC, Broadbent JM, Poulton R. Construct validity of Locker's global oral health item. J Dent Res. 2012 Nov;91(11):1038-42. doi: 10.1177/0022034512460676.

47. Jokovic A, Locker D, Stephens M, Kenny D, Tompson B, Guyatt G. Validity and reliability of a questionnaire for measuring child oral-health-related quality of life. J Dent Res. 2002 Jul;81(7):459-63.

48. Pitiphat W, Garcia RI, Douglass CW, Joshipura KJ. Validation of self-reported oral health measures. J Public Health Dent. 2002 Spring;62(2):122-8.

49. Eke PI, Dye B. Assessment of self-report measures for predicting population prevalence of periodontitis. J Periodontol. 2009 Sep;80(9):1371-9. doi: 10.1902/jop.2009.080607.

50. Abbood HM, Hinz J, Cherukara G, Macfarlane TV. Validity of Self-Reported Periodontal Disease: A Systematic Review and Meta-Analysis. J Periodontol. 2016 Dec;87(12):1474-83.

51. Chiga S, Ohba T, Tanoue D, Kawase H, Katoh T, Katabuchi H. Validity of Self-Reported Periodontal Disease Questionnaire among Pregnant Women. Nihon Eiseigaku Zasshi. 2016;71(3):260-6.

52. Joshipura KJ, Douglass CW, Garcia RI, Valachovic R, Willett WC. Validity of a self-reported periodontal disease measure. J Public Health Dent. 1996 Summer;56(4):205-12.

53. Farmer J, Ramraj C, Azarpazhooh A, Dempster L, Ravaghi V, Quinonez C. Comparing self-reported and clinically diagnosed unmet dental treatment needs using a nationally representative survey. J Public Health Dent. 2017 Sep;77(4):295-301. doi: 10.1111/jphd.12205. 
54. Jones K, Parker EJ, Jamieson LM. Access, literacy and behavioural correlates of poor self-rated oral health amongst an indigenous south Australian population. Community Dent Health. 2014 Sep;31(3):167-71.

55. Lee E, Lee YH, Kim W, Kho HS. Self-reported prevalence and severity of xerostomia and its related conditions in individuals attending hospital for general health examinations. Int J Oral Maxillofac Surg. 2014 Apr;43(4):498-505. doi: 10.1016/j.jjom.2013.10.011.

56. Bigler T, Filippi A. [Importance of halitosis. A survey of adolescents and young adults]. Swiss dental journal. 2016;126(4):347-59. German.

57. Kumar S, Kroon J, Lalloo R. A systematic review of the impact of parental socio-economic status and home environment characteristics on children's oral health related quality of life. Health Qual Life Outcomes. 2014 Mar 21;12:41. doi: 10.1186/1477-7525-12-41.

58. INEP. National Institute for Educational Studies and Research "Anísio Teixeira". [Statistical Synopsis of Higher Education 2015]. Brasília: INEP; 2016 [cited 2018 Jan 15]. Avaiable fron: http:IIportal.inep. gov.br/basica-censo-escolar-sinopse-sinopse. Portuguese. 